\title{
The Danish Network for Community Pharmacy Practice Research and Development
}

\author{
Alaa Burghle ${ }^{1,2, *}$, Rikke Nørgaard Hansen ${ }^{3}\left(D\right.$, Lotte Stig Nørgaard ${ }^{4}\left(0\right.$, , Ulla Hedegaard ${ }^{2}$, Susanne Bendixen ${ }^{5}$, \\ Lone Sondergaard ${ }^{6}$, Kerly Servilieri ${ }^{7}$, Julianne Hansen ${ }^{5}$ and Charlotte Rossing ${ }^{3}$
}

1 Hospital Pharmacy Funen, Odense University Hospital, 5000 Odense, Denmark

2 Clinical Pharmacology, Pharmacy and Environmental Medicine, Department of Public Health, University of Southern Denmark, 5000 Odense, Denmark; uhedegaard@health.sdu.dk

3 Department of Research and Development, Pharmakon, Danish College of Pharmacy Practice, 3400 Hilleroed, Denmark; rnh@pharmakon.dk (R.N.H.); cr@pharmakon.dk (C.R.)

4 Social and Clinical Pharmacy, Department of Pharmacy, Faculty of Health and Medical Sciences, University of Copenhagen, 2100 Copenhagen, Denmark; lotte.norgaard@sund.ku.dk

5 København Sønderbro Pharmacy, 2300 Copenhagen, Denmark; 199sb@apoteket.dk (S.B.); 199ju@apoteket.dk (J.H.)

6 Aarhus Viby Pharmacy, 8260 Viby J, Denmark; lone.soendergaard@mail.dk

7 Kløver Pharmacy Brædstrup, 8740 Brædstrup, Denmark; kerly@apoteket.dk

* Correspondence: alaa.hassan.burghle@rsyd.dk

Citation: Burghle, A.; Hansen, R.N.; Nørgaard, L.S.; Hedegaard, U.; Bendixen, S.; Søndergaard, L.; Servilieri, K.; Hansen, J.; Rossing, C. The Danish Network for Community Pharmacy Practice Research and Development. Pharmacy 2021, 9, 114. https://doi.org/10.3390/

pharmacy 9020114

Academic Editor: Hans De Loof

Received: 5 May 2021

Accepted: 13 June 2021

Published: 17 June 2021

Publisher's Note: MDPI stays neutral with regard to jurisdictional claims in published maps and institutional affiliations.

Copyright: (C) 2021 by the authors. Licensee MDPI, Basel, Switzerland. This article is an open access article distributed under the terms and conditions of the Creative Commons Attribution (CC BY) license (https:// creativecommons.org/licenses/by/ $4.0 /)$.

\begin{abstract}
The community pharmacy has a number of attributes that makes it an excellent setting for research and development projects, as it is a highly accessible part of the healthcare system and is staffed by highly trained health care professionals. The big turnover in patients in the community pharmacy makes it possible to reach a great number of patients and collect a lot of data in a relatively short time. However, conducting nation-wide research and development projects can be a rather time-consuming process for the individual community pharmacy, and can thus require collaboration with other community pharmacies and researchers. This will help ensure strong results and better implementation. Thus, the Danish Network for Community Pharmacy Practice for Research and Development (NUAP) was established in Denmark by a number of highly committed community pharmacies and researchers. NUAP consists of 102 member pharmacy owners in addition to a number of researchers. The aim of the network is to strengthen pharmacy practice and pharmacy practice research in Denmark by providing a forum where community pharmacy practitioners and researchers meet and work together. The network is led by a steering committee elected by the members in the network.
\end{abstract}

Keywords: pharmacy practice; network; pharmacy practice research; research network

\section{Introduction}

For the last couple of decades, pharmacy practice has moved from being primarily product-focused to being much more patient-focused [1]. Simultaneously, pharmacy practice research has become an increasingly accepted research field, which has been instrumental in generating evidence for the development of pharmacy health services [2-7].

The use of practice-based research networks to collect data and implementation of research results is common, and has been reported in the United States, United Kingdom, Europe, and Canada [8-11].

The community pharmacy has a number of attributes that makes it a unique and excellent setting for conducting research and development projects. Community pharmacies are highly accessible to patients [12], and are staffed by pharmacists and pharmacy technicians; two groups highly trained in many areas e.g., pharmacology, pharmacotherapy, and communication. Furthermore, the big turnover in customers in the community pharmacy setting [13] makes it possible to collect a large amount of data in a short time [14], and 
provides a healthcare setting where people in different states of health and illness come to pick up medication and seek medication-related counselling.

However, conducting nationwide research and development projects can be a resourceintensive and time-consuming process for the individual community pharmacy. Collaboration with other pharmacies and researchers might thus be necessary to ensure strong research results and more efficient implementation. Thus, the Danish Network for Community Pharmacy Practice Research and Development (NUAP) was established in Denmark by a number of highly committed community pharmacy owners and researchers in Denmark. NUAP is the abbreviation of Netværk for Udvikling af Apotekspraksis, the Danish name for the network.

In this paper, we will describe the projects included in NUAP and discuss what we have learned throughout the 5 years running the network.

\section{Community Pharmacies in Denmark}

All Danish residents who have been granted a residence permit have access to free healthcare, including visits to a general practitioner, hospital, emergency room, out-ofhour service, and so on. Denmark is divided into 5 regions and 98 municipalities [15]. Managing the hospital system is one of the regions' main tasks as well as organizing health care services by private practitioners [16], while the municipalities are responsible for the management of health care services at a local level [17].

By October 2020, a total of 506 community pharmacies (including pharmacy branches) exist in Denmark, divided between 201 pharmacy owners [13]. Danish community pharmacies are privately owned and have a monopoly on pharmacy practice, though some over-the-counter (OTC) medications are also sold in retail [18]. The Danish community pharmacy sector is regulated by the state, and is inspected by the Danish Patient Safety Authority and the Danish Medicines Agency along with other health care institutions [15]. On a yearly basis, community pharmacy staff meets the majority of the Danish population$94 \%$ of the population visited a community pharmacy in 2017 [19]. Thus, the Danish community pharmacies are responsible for distributing medications and counselling of patients about prescription medication and OTC medication. Additionally, community pharmacies support health promotion and implementation of correct medication use. Danish community pharmacies also deliver other pharmaceutical services for patients [7] e.g., The Inhaler Technique Assessment Service, New Medicines Service, and Re-prescribing Service. Danish community pharmacy staff consist of pharmacists holding a five-year MSc degree in pharmacy, pharmacy technicians holding a three-year academy profession degree, pharmacy technician students, and pharmacy internship students. Owning a community pharmacy is a right reserved for pharmacists in Denmark. An average community pharmacy consists of 12 staff members, while the average number of citizen per pharmacy is 12,000 citizens [13].

A total of 102 pharmacy owners are currently members of NUAP.

\section{Establishment and Structure of the Network}

Denmark has a long tradition for research and development in community pharmacy practice. For decades, a variety of community pharmacy research and development projects have been conducted both locally and nationally $[7,20]$. However, sharing knowledge and providing support in a structured manner and with full transparency toward stakeholders, researchers, and pharmacy practitioners has proven to be challenging and time-consuming. For this reason, NUAP was established in September 2016 as a network for Danish community pharmacies that are interested in research and development and established Danish researchers in pharmacy practice.

The formal members in the network are the pharmacy owners, but pharmacists or pharmacy technicians from their community pharmacy can represent them in the network. This structure is chosen, as research has found better results in implementation of new initiatives in the community pharmacy when this is supported by a strong leadership of 
the pharmacy owner [21]. Community pharmacy owners in all five Danish regions can join NUAP. Any community pharmacy owner interested in joining NUAP is required to send an e-mail with a request to join the network to the network secretariat. As a member, you commit yourself to participate in meetings, share knowledge and ideas, and to contribute whichever way you can in projects and dissemination of results.

The network is led by a steering committee that acts as a review board for project ideas submitted to the network by its current and future members. The steering committee consists of up to seven members. Four seats belong to representatives from member community pharmacies, while the remaining three seats belong to representatives from research institutions in the pharmacy practice field. The three research institutions represented are the University of Copenhagen, the University of Southern Denmark, and the Danish College of Pharmacy Practice (Pharmakon). The researchers on the board are appointed by their respective institutions.

The representatives from the community pharmacies serve in the steering committee for a two-year period and are elected by the members at the network's spring meeting. The four community pharmacy representatives must at least include one pharmacy owner, one pharmacist, and one pharmacy technician.

All projects that aspire to be accepted in the network must be submitted in writing in a defined template project description form for the steering committee to review (Appendix A). The template allows for a maximum of 450 words and covers the following topics: project title, background, aim, methods, timeline, dissemination plan, funding, project manager, and contact information for the project manager and his/her organization (Appendix A).

At present, 10 research and development projects are finalized, and 17 are ongoing.

\section{The Vision}

The overall aim of the network is to strengthen pharmacy practice and pharmacy practice research in Denmark by providing a forum where researchers and representatives of community pharmacies meet to share knowledge and support evidence-based community pharmacy practice. By meeting and working together, the aim of the network is to connect researchers and pharmacy practitioners in Denmark. This is done by creating and cultivating collaborative relationships between community pharmacies and researchers, inspiring new research and development projects, particularly projects rooted in the community pharmacies. Furthermore, the network aims to support transparency in projects and investigations performed in a Danish community pharmacy setting, enhancing project ideas that concern pharmacy practice and emphasize the role of the community pharmacy in relation to the rest of the Danish healthcare system. Additionally, the network aims to carry out projects that are relevant and applicable to future community pharmacy practice. Thus, the collaborative approach between researchers and practitioners enhances both the relevance for practice and the scientific quality of the results gained in the network. The network acts as a facilitator and a platform through which community pharmacies can participate in smaller or larger projects through collaboration with each other.

Finally, the network aims to create and disseminate results from research projects that can emphasize the value of community pharmacy to individual citizens and whole communities.

\section{How Does the Network Support its Members?}

The steering committee of the network is ready to provide help and support in projects and project ideas created by the members. Each project is assigned one member of the steering committee to provide support and feedback to the project managers from the community pharmacies (Figure 1). 


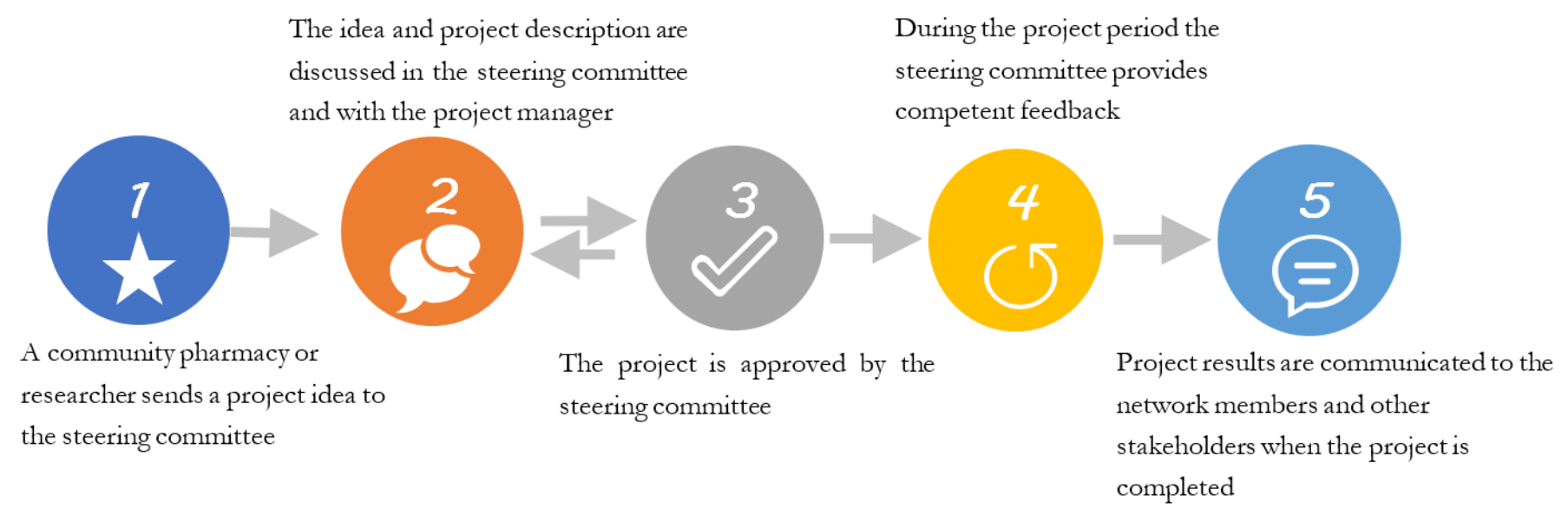

Figure 1. A project's journey from idea to result dissemination in the Danish Network for Community Pharmacy Practice (NUAP).

Further, the steering committee invites all members to a network meeting biannually to discuss new project ideas, developments in ongoing projects, and results from completed projects in the network in addition to other subjects related to pharmacy practice. The biannual network meetings also serve as a forum where members from different community pharmacies from all over Denmark meet, exchange knowledge and experiences, and establish collaborations. The network meetings are conducted either online or as physical meetings. Future meetings will, hopefully, be conducted as a combination of both.

Network members are able to discuss a project idea or a project description with the steering committee at a monthly, open online meeting. Additionally, supporting tools for conducting projects are available on the network's website e.g., video tutorials about how to carry out a project in a community pharmacy and how to disseminate results.

Participating in the network provides the community pharmacy members with a number of opportunities for inspiration and learning. First, members are, at network meetings and in newsletters, presented with experiences of other members working on different projects. Second, members can share ideas on new pharmaceutical services and other research and development projects that stem from their practice at the community pharmacy. Third, members can participate in a review of practice in the Danish community pharmacies, for which researchers or other project managers ask for input from the practitioners in the network e.g., on how patients with low health literacy or patients who have a poor hearing are supported at the pharmacy. Fourth, the link and collaboration between pharmacy staff and researchers at the universities can contribute to retaining talented and skilled pharmacists and pharmacy technicians in the community pharmacy sector. Last, through participating in the network, community pharmacies have an opportunity to contribute to research and development of pharmacy practice in Denmark and take ownership of the development of their sector along with other community pharmacies and researchers in the field.

Furthermore, members receive help with data processing and dealing with ethical approvals and GDPR regulations from members who are experienced in obtaining such approvals and with working with GDPR (mainly researchers). All projects that involve sensitive personal data are to be approved by either the Regional or National Committee on Health Research Ethics or by the GDPR supervisors in the Danish region in which the project is registered or at one of the universities participating in the project. Both the Committees on Health Research Ethics and GDPR supervisors can waive approval of the project, if they deem such approvals unnecessary. All data collected in research and development projects under NUAP are stored and processed securely, either in secured digital databases or physically in a secure place at the community pharmacies involved in the project in compliance with GDPR regulations. 
Some community pharmacies complete and implement projects at their pharmacy all the time, but they seek collaborators for their projects, while other community pharmacies find the network a great opportunity to participate in others' projects. The network thus creates a win-win situation for both parties.

Community pharmacies and researchers ask for support and competent feedback in different phases of their projects. Thus, the network provides a platform for practitioners and researchers to learn from each other and optimize their research and development projects. The network provides the participating community pharmacies a platform of communicating their results on the network website [22], at network meetings, and in newsletters.

\section{What Have We Learned So Far?}

The members of the network have conducted a large number of studies under a variety of topics and used different methods (Table 1). Some projects have been disseminated through other channels than those displayed in Table 1, e.g., relevant periodicals. Researchers and community pharmacy practitioners alike have initiated projects conducted in the network. Many lessons have been learned through every process involved in the conducted projects, for example:

- The importance of establishing the project group with an allocated project manager to ensure support for the project;

- To ensure that the project yields valid data and robust results, it is important to involve both practitioners and researchers;

- When conducting a project with several community pharmacies participating, it is important to conduct a kick-off meeting with representatives from all participating pharmacies;

- Thorough instructions for the participants and follow up during data collection are important for a successful result;

- Participation in larger projects can enhance the sense of purpose, meaningfulness, and competency for many community pharmacy practitioners and pharmacy practice researchers;

- Participation in research and development projects results in useful knowledge to enhance the daily dialogue and counselling with customers at the pharmacy counter. 
Table 1. Ongoing and completed projects in the Danish Network for Community Pharmacy Practice (NUAP).

\begin{tabular}{|c|c|c|c|c|c|c|c|}
\hline Year & Project Title & Aim & Participants & Data Collection & Dissemination & Project Type & Conclusions \\
\hline \multicolumn{8}{|c|}{ Completed projects } \\
\hline 2017 & $\begin{array}{l}\text { Reduction in } \\
\text { long-term treatment } \\
\text { with proton pump } \\
\text { inhibitors (PPIs) }\end{array}$ & $\begin{array}{l}\text { To quantify the use } \\
\text { of PPI for regular } \\
\text { users to determine } \\
\text { how many use it } \\
\text { regularly and to } \\
\text { examine how many } \\
\text { have tried to } \\
\text { discontinue their } \\
\text { PPI-treatment }\end{array}$ & $\begin{array}{c}395 \text { community } \\
\text { pharmacy customers }\end{array}$ & Interviews & $\begin{array}{c}\text { Poster at Nordic } \\
\text { Social Pharmacy and } \\
\text { Health Services } \\
\text { Research Conference } \\
\text { (NSPC) [23] } \\
\text { Video presentation } \\
\text { [24] }\end{array}$ & Development project & $\begin{array}{l}\text { A large proportion of PPI } \\
\text { users ( } 80 \%) \text { use their } \\
\text { medicine continuously. } \\
\text { The leaflet information } \\
\text { was a useful tool to } \\
\text { provide essential } \\
\text { information to new users } \\
\text { in addition to counceling } \\
\text { at the community } \\
\text { pharmacy counter. }\end{array}$ \\
\hline 2018 & $\begin{array}{c}\text { Customers' } \\
\text { information seeking } \\
\text { behavior prior to } \\
\text { community } \\
\text { pharmacy visits: a } \\
\text { community } \\
\text { pharmacy survey }\end{array}$ & $\begin{array}{c}\text { To quantify and } \\
\text { describe customers' } \\
\text { information seeking } \\
\text { behavior prior to } \\
\text { community } \\
\text { pharmacy visits, and } \\
\text { to describe how } \\
\text { pharmacy staff } \\
\text { utilize information } \\
\text { obtained by } \\
\text { customers. }\end{array}$ & $\begin{array}{c}2623 \text { community } \\
\text { pharmacy customers }\end{array}$ & Survey & $\begin{array}{c}\text { Burghle et al. [14] } \\
\text { Posters at } \\
\text { international } \\
\text { conferences: } \\
\text { Pharmaceutical Care } \\
\text { Network Europe } \\
\text { (PCNE) and Nordic } \\
\text { Social Pharmacy and } \\
\text { Health Services } \\
\text { Research Conference } \\
\text { (NSPC) } \\
\text { Video presentation } \\
\text { [25] }\end{array}$ & Descriptive study & $\begin{array}{l}\text { A total of } 14.4 \% \text { of } \\
\text { customers had sought } \\
\text { information prior to } \\
\text { visiting the community } \\
\text { pharmacy. } \\
\text { The majority of } \\
\text { customers had used } \\
\text { reliable sources, and the } \\
\text { information was used } \\
\text { during pharmacy } \\
\text { counselling. }\end{array}$ \\
\hline 2018 & $\begin{array}{l}\text { Interdisciplinary } \\
\text { collaboration } \\
\text { between community } \\
\text { pharmacy and } \\
\text { general practitioner }\end{array}$ & $\begin{array}{l}\text { To describe what } \\
\text { characterizes the } \\
\text { Danish pharmacies' } \\
\text { interdisciplinary } \\
\text { collaboration with } \\
\text { the general } \\
\text { practitioner in the } \\
\text { primary sector.. }\end{array}$ & $\begin{array}{l}29 \text { community } \\
\text { pharmacy staff } \\
\text { members }\end{array}$ & Survey & $\begin{array}{c}\text { Master thesis report } \\
{[26]}\end{array}$ & Descriptive study & $\begin{array}{l}\text { The interdisciplinary } \\
\text { collaboration between } \\
\text { the pharmacy and the } \\
\text { general practitioner in } \\
\text { the primary sector was } \\
\text { characterized by a high } \\
\text { level of 'trust', 'mutual } \\
\text { professional respect', and } \\
\text { a clear 'role distribution'. }\end{array}$ \\
\hline
\end{tabular}


Table 1. Cont.

\begin{tabular}{|c|c|c|c|c|c|c|c|}
\hline Year & Project Title & Aim & Participants & Data Collection & Dissemination & Project Type & Conclusions \\
\hline \multicolumn{8}{|c|}{ Completed projects } \\
\hline 2018 & $\begin{array}{c}\text { Unavailable } \\
\text { prescriptions at } \\
\text { Danish community } \\
\text { pharmacies: A } \\
\text { descriptive study }\end{array}$ & $\begin{array}{l}\text { To describe the } \\
\text { occurrence and } \\
\text { reasons for } \\
\text { unavailable } \\
\text { prescriptions at } \\
\text { Danish community } \\
\text { pharmacies as well } \\
\text { as the types of drugs } \\
\text { involved }\end{array}$ & $\begin{array}{l}2765 \text { prescriptions } \\
\text { registered }\end{array}$ & Survey & $\begin{array}{c}\text { Lundby et al. [27] } \\
\text { Master thesis by } \\
\text { Anne Vejrum Nielsen } \\
\text { [28] }\end{array}$ & Descriptive study & $\begin{array}{l}\text { Unavailable } \\
\text { prescriptions occur in } \\
\text { approximately } 1 \% \text { of all } \\
\text { dispensing at Danish } \\
\text { community pharmacies. } \\
\text { Miscommunication } \\
\text { between the patient and } \\
\text { general practitioner } \\
\text { seems to be the primary } \\
\text { source of unavailable } \\
\text { prescriptions. }\end{array}$ \\
\hline 2018 & $\begin{array}{l}\text { Danish physicians' } \\
\text { and pharmacists' } \\
\text { knowledge, attitude, } \\
\text { and behavior } \\
\text { regarding antibiotics } \\
\text { for children under } \\
\text { the age of } 15\end{array}$ & $\begin{array}{l}\text { To describe the } \\
\text { knowledge, attitudes, } \\
\text { and actions of } \\
\text { physicians and } \\
\text { community } \\
\text { pharmacists } \\
\text { regarding antibiotics } \\
\text { for children under } \\
\text { the age of } 15\end{array}$ & $\begin{array}{c}8 \text { interviews and } 762 \\
\text { prescriptions } \\
\text { registered }\end{array}$ & $\begin{array}{l}\text { Semi-structured } \\
\text { interviews and a } \\
\text { cross-sectional } \\
\text { survey }\end{array}$ & $\begin{array}{c}\text { Master thesis report } \\
\text { [29] }\end{array}$ & $\begin{array}{l}\text { Descriptive and } \\
\text { qualitative study }\end{array}$ & $\begin{array}{l}\text { Physicians and } \\
\text { pharmacists are aware of } \\
\text { the appropriate use of } \\
\text { antibiotics and antibiotic } \\
\text { resistance. Physicians } \\
\text { deviate from guidelines, } \\
\text { though, when } \\
\text { prescribing antibiotics in } \\
\text { regard to choice of } \\
\text { antibiotic type and dose. }\end{array}$ \\
\hline 2018 & $\begin{array}{l}\text { Roundtable between } \\
\text { community } \\
\text { pharmacy and } \\
\text { homecare to support } \\
\text { patient safety }\end{array}$ & $\begin{array}{l}\text { To test roundtable } \\
\text { meetings between } \\
\text { community } \\
\text { pharmacy and } \\
\text { homecare staff } \\
\text { regarding } \\
\text { medication }\end{array}$ & $\begin{array}{l}\text { Four community } \\
\text { pharmacies and four } \\
\text { municipalities }\end{array}$ & $\begin{array}{l}\text { Surveys and online } \\
\text { meeting minutes }\end{array}$ & $\begin{array}{c}\text { Report by Pultz et al. } \\
\text { [30] } \\
\text { Poster at } \\
\text { Pharmaceutical Care } \\
\text { network Europe } \\
\text { (PCNE) }\end{array}$ & Development project & $\begin{array}{l}\text { The roundtables had a } \\
\text { positive influence on } \\
\text { quality and safety in } \\
\text { medication management } \\
\text { and are very relevant for } \\
\text { the daily work in } \\
\text { homecare. Additionally, } \\
\text { homecare staff should be } \\
\text { involved in planning the } \\
\text { content of the } \\
\text { roundtables and } \\
\text { prioritizing topics. }\end{array}$ \\
\hline
\end{tabular}


Table 1. Cont.

\begin{tabular}{|c|c|c|c|c|c|c|c|}
\hline Year & Project Title & Aim & Participants & Data Collection & Dissemination & Project Type & Conclusions \\
\hline \multicolumn{8}{|c|}{ Completed projects } \\
\hline 2019 & $\begin{array}{l}\text { Evaluation of the } \\
\text { Danish Network for } \\
\text { Community } \\
\text { Pharmacy Practice } \\
\text { Research and } \\
\text { Development }\end{array}$ & $\begin{array}{l}\text { To explore the attitudes of } \\
\text { community pharmacy staff } \\
\text { on the Danish network for } \\
\text { Community Pharmacy } \\
\text { Practice Research and } \\
\text { Development }\end{array}$ & $\begin{array}{l}41 \text { community } \\
\text { pharmacy staff }\end{array}$ & Survey & $\begin{array}{l}\text { Report by Julie } \\
\text { Valentin [31] } \\
\text { Posters at Nordic } \\
\text { Social Pharmacy and } \\
\text { Health Services } \\
\text { Research Conference } \\
\text { (NSPC) [32] and at } \\
\text { FIP-congress 2018 }\end{array}$ & Descriptive study & $\begin{array}{l}\text { Members of the network } \\
\text { were generally satisfied } \\
\text { with the management of } \\
\text { the network. However, } \\
\text { they had some suggestions } \\
\text { for improvements e.g., and } \\
\text { idea bank for their project } \\
\text { ideas and a newsletter sent } \\
\text { directly to their work } \\
\text { e-mail regarding the status } \\
\text { of the projects in the } \\
\text { network. }\end{array}$ \\
\hline 2019 & $\begin{array}{l}\text { Communication } \\
\text { between pharmacy } \\
\text { staff and older } \\
\text { migrants }\end{array}$ & $\begin{array}{l}\text { To investigate the } \\
\text { communication between } \\
\text { older migrants and } \\
\text { pharmacy staff at the } \\
\text { community pharmacy } \\
\text { counter }\end{array}$ & $\begin{array}{c}152 \text { community } \\
\text { pharmacy customers }\end{array}$ & Survey & $\begin{array}{l}\text { Master thesis report } \\
\text { [33] }\end{array}$ & Descriptive study & $\begin{array}{l}\text { This pilot study indicates } \\
\text { that older migrants with } \\
\text { language barriers receive } \\
\text { less and more basic } \\
\text { medical information at the } \\
\text { community pharmacy } \\
\text { compared with customers } \\
\text { who are Danish native } \\
\text { speakers. }\end{array}$ \\
\hline 2020 & $\begin{array}{l}\text { COVID-19 at the } \\
\text { University of } \\
\text { Copenhagen's } \\
\text { internship } \\
\text { pharmacies-spring } \\
\text { semester 2020 }\end{array}$ & $\begin{array}{l}\text { To describe the experiences } \\
\text { and reflections of pharmacy } \\
\text { internship students from } \\
\text { University of Copenhagen } \\
\text { about the impact of } \\
\text { COVID-19 on Danish } \\
\text { community pharmacies }\end{array}$ & $\begin{array}{c}47 \text { pharmacy } \\
\text { internship students }\end{array}$ & Survey & $\begin{array}{l}\text { Presentation at FIP } \\
\text { virtual conference } \\
2020[34]\end{array}$ & Qualitative study & $\begin{array}{l}\text { The students gave, among } \\
\text { other things, } 12 \\
\text { suggestions for what they } \\
\text { think could be maintained } \\
\text { after the corona pandemic, } \\
\text { e.g., meeting culture, social } \\
\text { distancing, training in crisis } \\
\text { preparedness. }\end{array}$ \\
\hline 2020 & $\begin{array}{l}\text { Experiences with } \\
\text { abuse of } \\
\text { over-the-counter } \\
\text { medication in the } \\
\text { community } \\
\text { pharmacy }\end{array}$ & $\begin{array}{l}\text { To describe Danish } \\
\text { pharmacy pharmacists' } \\
\text { experience in regard to } \\
\text { customers and their abuse } \\
\text { of over-the-counter } \\
\text { medicine }\end{array}$ & $\begin{array}{l}\text { Seven sommunity } \\
\text { pharmacists }\end{array}$ & $\begin{array}{l}\text { Semi-structured } \\
\text { interviews }\end{array}$ & $\begin{array}{c}\text { Master thesis report } \\
{[35]}\end{array}$ & Qualitative study & $\begin{array}{l}\text { The pharmacists in this } \\
\text { study all had experiences } \\
\text { with customers abusing } \\
\text { over-the-counter drugs. } \\
\text { Pharmacy pharmacist } \\
\text { experience abuse of } \\
\text { over-the-counter drugs on } \\
\text { a weekly basis. } \\
\text { Identification of abuse } \\
\text { takes place through } \\
\text { identification of needs, and } \\
\text { attempts are made to deal } \\
\text { with it through counseling }\end{array}$ \\
\hline
\end{tabular}


Table 1. Cont.

\begin{tabular}{|c|c|c|c|c|c|c|c|}
\hline Year & Project Title & Aim & Participants & Data Collection & Dissemination & Project Type & Conclusions \\
\hline \multicolumn{8}{|c|}{$\begin{array}{l}\text { Completed projects } \\
\text { Ongoing projects }\end{array}$} \\
\hline 2016 & $\begin{array}{l}\text { Improving } \\
\text { counselling at the } \\
\text { community } \\
\text { pharmacy }\end{array}$ & $\begin{array}{l}\text { To explore different ways } \\
\text { to improve counselling at } \\
\text { the community pharmacy }\end{array}$ & $\begin{array}{c}\text { Pilot study: } \\
\text { Two community } \\
\text { pharmacies } \\
\text { Intervention study: } \\
30 \text { pharmacists and } \\
\text { pharmacy } \\
\text { technicians from } \\
\text { community } \\
\text { pharmacies }\end{array}$ & $\begin{array}{l}\text { Literature review } \\
\text { Focus group } \\
\text { interviews } \\
\text { Observational and } \\
\text { interview study } \\
\text { Test and survey }\end{array}$ & $\begin{array}{c}\text { Kaae et al. [36] } \\
\text { Fosgerau, Kaae [37] }\end{array}$ & Development project & \\
\hline 2017 & $\begin{array}{l}\text { The pharmacist as a } \\
\text { bridge-builder in the } \\
\text { transition of care at } \\
\text { discharge }\end{array}$ & $\begin{array}{c}\text { To to develop and test a } \\
\text { cross-sectoral } \\
\text { pharmacist-to-pharmacist } \\
\text { service to optimize drug } \\
\text { treatment and drug } \\
\text { information at sector } \\
\text { transitions } \\
\end{array}$ & $\begin{array}{c}6 \text { community } \\
\text { pharmacists and } \\
\text { clinical pharmacists } \\
\text { from hospital }\end{array}$ & $\begin{array}{c}\text { Focus group } \\
\text { interviews } \\
\text { Individual } \\
\text { interviews } \\
\text { Documentation of } \\
\text { practice via survey }\end{array}$ & $\begin{array}{l}\text { Lech et al. [38] } \\
\text { Poster presentation } \\
\text { at Nordic Social } \\
\text { Pharmacy and } \\
\text { Health Services } \\
\text { Research Conference } \\
\text { (NSPC) [39] } \\
\end{array}$ & $\begin{array}{l}\text { Development project } \\
\text { (PhD project) }\end{array}$ & \\
\hline 2019 & $\begin{array}{l}\text { Quality of pregnancy } \\
\text { prevention in women } \\
\text { using teratogenic } \\
\text { drugs }\end{array}$ & $\begin{array}{l}\text { To explore patients' and } \\
\text { healthcare professionals' } \\
\text { knowledge about } \\
\text { pregnancy prevention in } \\
\text { women who use } \\
\text { teratogenic drugs } \\
\end{array}$ & 103 patients & Survey & Ongoing & Descriptive study & \\
\hline 2019 & $\begin{array}{l}\text { Scope and practice of } \\
\text { re-prescribing in } \\
\text { Danish community } \\
\text { pharmacies }\end{array}$ & $\begin{array}{l}\text { To explore practices for the } \\
\text { re-prescribing service, with } \\
\text { regard to providing input } \\
\text { to community pharmacies, } \\
\text { the Danish Health } \\
\text { Authority, educators, and } \\
\text { interest organizations in } \\
\text { relation to the status, } \\
\text { implementation, and } \\
\text { development of the service. }\end{array}$ & $\begin{array}{l}125 \text { re-prescribing } \\
\text { situations registered }\end{array}$ & Survey & Ongoing & Descriptive study & \\
\hline
\end{tabular}


Table 1. Cont.

\begin{tabular}{|c|c|c|c|c|c|c|c|}
\hline Year & Project Title & Aim & Participants & Data Collection & Dissemination & Project Type & Conclusions \\
\hline 2020 & $\begin{array}{l}\text { Data-driven dialogue } \\
\text { on medical } \\
\text { adherence in Danish } \\
\text { community } \\
\text { pharmacies with the } \\
\text { help of Klikkit's } \\
\text { telehealth solution }\end{array}$ & $\begin{array}{l}\text { To test the KlikKit } \\
\text { technology to support } \\
\text { patients at three selected } \\
\text { pharmacies, and to assess } \\
\text { how the overview of } \\
\text { patients' medication use } \\
\text { can be included in a } \\
\text { consultation about } \\
\text { compliance }\end{array}$ & Ongoing & $\begin{array}{l}\text { Focus group } \\
\text { interviews }\end{array}$ & Ongoing & Development project & \\
\hline 2020 & $\begin{array}{l}\text { Triple whammy } \\
\text { effect—safe use of } \\
\text { NSAIDs }\end{array}$ & $\begin{array}{l}\text { To explore the number of } \\
\text { customers who use the } \\
\text { triple whammy } \\
\text { combination, including } \\
\text { both customers who } \\
\text { receive NSAIDs on } \\
\text { prescription and customers } \\
\text { who buy NSAIDs over the } \\
\text { counter. Furthermore, to } \\
\text { disseminate awareness of } \\
\text { the triple whammy effect } \\
\text { among pharmacy staff and } \\
\text { customers }\end{array}$ & Ongoing & $\begin{array}{c}\text { Patient survey and } \\
\text { documentation of } \\
\text { practice } \\
\text { Survey for the } \\
\text { pharmacy staff }\end{array}$ & Ongoing & Development project & \\
\hline 2020 & $\begin{array}{l}\text { Narrative Medicine } \\
\text { in pharmacy } \\
\text { practice—a feasibility } \\
\text { study }\end{array}$ & $\begin{array}{l}\text { To develop a course in } \\
\text { narrative medicine for } \\
\text { community pharmacists } \\
\text { and to investigate the } \\
\text { feasibility of the course and } \\
\text { the effect of the training on } \\
\text { the empathic skills of } \\
\text { pharmacists }\end{array}$ & Ongoing & $\begin{array}{c}\text { Educational course } \\
\text { in narrative medicine } \\
\text { for pharmacists } \\
\text { Survey }\end{array}$ & Ongoing & Development project & \\
\hline 2020 & $\begin{array}{l}\text { Drug shortages in } \\
\text { community } \\
\text { pharmacies }\end{array}$ & $\begin{array}{l}\text { To explore the extent of } \\
\text { drug shortages in Danish } \\
\text { community pharmacies }\end{array}$ & Ongoing & Survey & Ongoing & Descriptive study & \\
\hline
\end{tabular}


Table 1. Cont.

\begin{tabular}{|c|c|c|c|c|c|c|c|}
\hline Year & Project Title & Aim & Participants & Data Collection & Dissemination & Project Type & Conclusions \\
\hline \multicolumn{8}{|c|}{ Completed projects } \\
\hline 2020 & $\begin{array}{l}\text { Instruction of } \\
\text { patients in using the } \\
\text { positive expriatory } \\
\text { pressure (PEP) } \\
\text { device at the } \\
\text { community } \\
\text { pharmacy }\end{array}$ & $\begin{array}{l}\text { To develop the service } \\
\text { "Instruction in the use of } \\
\text { PEP at community } \\
\text { pharmacies in Aarhus" }\end{array}$ & Ongoing & $\begin{array}{l}\text { Observations } \\
\text { Interviews }\end{array}$ & Ongoing & Development project & \\
\hline 2020 & $\begin{array}{l}\text { Customers' wishes } \\
\text { and attitudes } \\
\text { towards the } \\
\text { COVID-19 antibody } \\
\text { test }\end{array}$ & $\begin{array}{l}\text { To explore the customers' } \\
\text { motivations for taking the } \\
\text { test at the community } \\
\text { pharmacy, their } \\
\text { expectations for the use of } \\
\text { the results, and their } \\
\text { attitude towards the price } \\
\text { of the test }\end{array}$ & Ongoing & Survey & Ongoing & Development project & \\
\hline 2021 & $\begin{array}{l}\text { Validation of Living } \\
\text { with Medicines } \\
\text { Questionnaire }\end{array}$ & $\begin{array}{l}\text { To conduct a translation, } \\
\text { cross-cultural adaptation } \\
\text { and validation of a Danish } \\
\text { version of the Living with } \\
\text { Medicines Questionnaire }\end{array}$ & Ongoing & $\begin{array}{c}\text { Translation and } \\
\text { cross-cultural } \\
\text { adaptation using } \\
\text { forward and } \\
\text { backward translation }\end{array}$ & Ongoing & Validation study & \\
\hline 2021 & $\begin{array}{l}\text { Implementation of } \\
\text { screening for } \\
\text { streptococcus A at } \\
\text { the pharmacy }\end{array}$ & $\begin{array}{l}\text { To explore the attitudes of } \\
\text { general practitioners and } \\
\text { community pharmacits on } \\
\text { implementing a test for } \\
\text { streptococcus A at the } \\
\text { community pharmacy }\end{array}$ & Ongoing & Interviews & Ongoing & Qualitative study & \\
\hline 2021 & $\begin{array}{l}\text { The community } \\
\text { pharmacy and } \\
\text { cancer-related late } \\
\text { effects }\end{array}$ & $\begin{array}{l}\text { To explore how many } \\
\text { current and former cancer } \\
\text { patients with late effects } \\
\text { come to the community } \\
\text { pharmacies, their needs } \\
\text { and wishes, and whether } \\
\text { they are interested in } \\
\text { receiving support from a } \\
\text { community pharmacist to } \\
\text { deal with cancer-related } \\
\text { late complications }\end{array}$ & Ongoing & Survey & Ongoing & Descriptive study & \\
\hline
\end{tabular}


Table 1. Cont.

\begin{tabular}{|c|c|c|c|c|c|c|c|}
\hline Year & Project Title & Aim & Participants & Data Collection & Dissemination & Project Type & Conclusions \\
\hline 2021 & $\begin{array}{c}\text { Patients' } \\
\text { perspectives on the } \\
\text { deprescribing } \\
\text { process }\end{array}$ & $\begin{array}{l}\text { To explore the patient } \\
\text { perspective in the } \\
\text { deprescribing process. In } \\
\text { addition, the project aims } \\
\text { to describe the extent to } \\
\text { which and how patients see } \\
\text { role of the community } \\
\text { pharmacy in the } \\
\text { deprescribing process }\end{array}$ & Ongoing & leted projects & Ongoing & Qualitative study & \\
\hline 2021 & $\begin{array}{l}\text { Use of pain } \\
\text { medication in } \\
\text { Denmark: A } \\
\text { community } \\
\text { pharmacy survey }\end{array}$ & $\begin{array}{l}\text { To explore the use of } \\
\text { analgesics among Danish } \\
\text { community pharmacy } \\
\text { customers }\end{array}$ & Ongoing & Survey & Ongoing & Descriptive study & \\
\hline 2021 & $\begin{array}{c}\text { Is the patient } \\
\text { information leaflet } \\
\text { necessary? }\end{array}$ & $\begin{array}{l}\text { To explore the use of the } \\
\text { paper-based patient } \\
\text { information leaflets in } \\
\text { medication packages by } \\
\text { community pharmacy } \\
\text { customers vs. the use of } \\
\text { digital alternatives }\end{array}$ & Ongoing & Survey & Ongoing & Descriptive study & \\
\hline 2021 & $\begin{array}{c}\text { Sustainable } \\
\text { conversion of } \\
\text { community } \\
\text { pharmacies and } \\
\text { medicine use in } \\
\text { Denmark in a Nordic } \\
\text { perspective-a study } \\
\text { of the role and } \\
\text { perceptions of } \\
\text { Danish community } \\
\text { pharmacy staff }\end{array}$ & $\begin{array}{l}\text { To examine the Danish } \\
\text { community pharmacies in } \\
\text { a sustainable context and to } \\
\text { describe and understand } \\
\text { the community pharmacies' } \\
\text { perception and role in the } \\
\text { sustainable development of } \\
\text { Danish community } \\
\text { pharmacies and the } \\
\text { sustainable transition of } \\
\text { medicine use in Denmark }\end{array}$ & Ongoing & $\begin{array}{c}\text { Survey } \\
\text { Interviews }\end{array}$ & Ongoing & $\begin{array}{l}\text { Descriptive and } \\
\text { qualitative study }\end{array}$ & \\
\hline
\end{tabular}


The projects in NUAP have a very wide range in both scope and methodology, and have involved both urban and rural community pharmacies from all five Danish regions in all stages of research and development work through projects. Working with the projects in NUAP helps develop and improve pharmacy practice by e.g., involving the community pharmacy in collaborations with other community pharmacies or other stakeholders like municipal homecare to strengthen medication safety for the medicine user. Working within NUAP has made practitioners and researchers work more closely together to research and develop pharmacy practice in Denmark in a way that makes sense in practice.

We hope to read similar reports in the future about relevant initiatives in pharmacy practice from other countries for inspiration and possible future international collaborations.

\section{What Does the Future Hold for the Network?}

The network aims to be the foundation of a strong and national pharmacy practice research environment in Denmark. This can, hopefully, inspire future pharmacy technicians and pharmacists to stay in the community pharmacy sector and to pursue further involvement with the development of the community pharmacy as a platform for delivery of healthcare to the population [7].

The network is now at a stage where dissemination of project results is vital for pharmacy practice and for researchers. The projects are running smoothly and the knowledge generated should be communicated continuously to both researchers and practitioners.

In the future, NUAP seeks to establish international collaborations with other pharmacy practice networks.

\section{Conclusions}

So far, 27 projects have been accepted in the network, of which 10 are finalized.

In conclusion, the network ensures a platform for national knowledge sharing in pharmacy practice, which is advantageous for researchers and practitioners. Researchers have access to a great number of community pharmacies for data collection for small and big research projects, and being part of a vast network gives small community pharmacies the opportunity to contribute to the development of Danish community pharmacy practice on equal terms with larger community pharmacies. This gives the network the potential to become an important Danish development and research resource.

In the future, the steering committee and members of NUAP are interested in working more on integration of the results from projects conducted in the network in all community pharmacies. This can be done by e.g., continuing to work on more practice-based projects that are highly relevant for community pharmacy practice, disseminating results of projects more efficiently both nationally and internationally, and involving more pharmacy technicians as they are the largest staff group in Danish community pharmacies.

In its first five years, the network has experienced a great willingness from Danish community pharmacies to contribute to the development of community pharmacy practice in Denmark. Dissemination of project and research results in the network will increase the visibility of Danish community pharmacy practice and, hopefully, contribute to its development.

Funding: This research received no external funding.

Institutional Review Board Statement: Not applicable.

Informed Consent Statement: Not applicable.

Data Availability Statement: Not applicable.

Conflicts of Interest: The authors declare no conflict of interest.

Read More: The NUAP website (Danish): https: / / www.pharmakon.dk/forskning/apoteksnetvaerk/. To contact NUAP, please send an email to the secretariat at paps@pharmakon.dk. 


\section{Appendix A}

Project description template.

\begin{tabular}{|c|c|}
\hline Project Title: & Triple Whammy-Safe Use of NSAIDs \\
\hline Background: & $\begin{array}{l}\text { It is well documented that the combination of diuretics and an ACE } \\
\text { inhibitor (or angiotensin II receptor antagonist) with NSAIDs presents a } \\
\text { risk of acute renal failure. } \\
\text { The combination is known as triple whammy. The combination can } \\
\text { result in a } 31 \% \text { increased risk of acute renal failure-the risk is doubled } \\
\text { within the first } 30 \text { days of treatment with NSAIDs. } \\
\text { Together, the three drug groups, used alone or in combination, account } \\
\text { for more than half of reported cases of drug-induced acute renal failure. } \\
\text { Older adults are especially at risk as kidney function deteriorates } \\
\text { with age. } \\
\text { As community pharmacy staff meet many patients every day, and } \\
\text { possess knowledge about medication, there is a possibility that they can } \\
\text { help these customers in their daily counselling, as well as those who may } \\
\text { want to buy NSAIDs in retail in the future, without receiving counselling. }\end{array}$ \\
\hline Aim: & $\begin{array}{l}\text { To quantify customers who use the triple whammy drug combination, } \\
\text { including both customers who receive NSAIDs on prescription and } \\
\text { customers who buy NSAIDs over the counter. } \\
\text { To describe the awareness of the triple whammy effect among pharmacy } \\
\text { staff and customers. } \\
\text { Introducing and implementing an information leaflet on the triple } \\
\text { whammy effect, as part of the counselling to these customers. }\end{array}$ \\
\hline $\begin{array}{l}\text { Design and } \\
\text { methods: }\end{array}$ & $\begin{array}{l}\text { Information about counselling of all patients who come to the pharmacy } \\
\text { to buy any kind of NSAID, both prescription and OTC, will be registered } \\
\text { by pharmacy staff. Data collection via digital survey. }\end{array}$ \\
\hline Timeframe: & January 2020-May 2021 \\
\hline Dissemination plan: & $\begin{array}{l}\text { Peer-reviewed paper, video presentations, articles in relevant Danish } \\
\text { periodicals }\end{array}$ \\
\hline Project manager: & Anne Mette Jørgensen, Pharmacist at Stege Pharmacy \\
\hline $\begin{array}{l}\text { Contact } \\
\text { information: }\end{array}$ & \\
\hline
\end{tabular}

\begin{tabular}{l}
$\begin{array}{l}\text { Organization: } \\
\text { (Community phar- } \\
\text { macy/researcher } \\
\text { etc.) }\end{array}$ \\
\hline $\begin{array}{l}\text { Funding } \\
\text { Which member of } \\
\text { the steering } \\
\text { committee do yound } \\
\text { wish to work with? }\end{array}$ \\
\hline
\end{tabular}

\section{References}

1. van Mil, J.W.F. Pharmaceutical care in community pharmacy: Practice and research in the Netherlands. Ann. Pharmacother. 2005, 39, 1720-1725. [CrossRef] [PubMed]

2. Herborg, P.D.H. Safe and Effective Use of Medicines for Ethnic Minorities-A Pharmacist- Delivered Counseling Program That Improves Adherence. J. Pharm. Care Health Syst. 2015, 2, 2. [CrossRef]

3. Kjeldsen, L.J.; Bjerrum, L.; Dam, P.; Larsen, B.O.; Rossing, C.; Søndergaard, B.; Herborg, H. Safe and effective use of medicines for patients with type 2 diabetes-A randomized controlled trial of two interventions delivered by local pharmacies. Res. Soc. Adm. Pharm. 2015, 11, 47-62. [CrossRef] [PubMed]

4. Herborg, H.; Soendergaard, B.; Froekjaer, B.; Fonnesbaek, L.; Jorgensen, T.; Hepler, C.D.; Grainger-Rousseau, T.J.; Ersboell, B.K. Improving drug therapy for patients with asthma—Part 1: Patient outcomes. J. Am. Pharm. Assoc. 2001, 41, 539-550. [CrossRef] 
5. Herborg, H.; Soendergaard, B.; Jorgensen, T.; Fonnesbaek, L.; Hepler, C.D.; Holst, H.; Froekjaer, B. Improving drug therapy for patients with asthma-part 2: Use of antiasthma medications. J. Am. Pharm. Assoc. 2001, 41, 551-559. [CrossRef]

6. Hopp, T.R.; Klinke, B.O.; Sørensen, E.W.; Herborg, H. Roberts Implementation of cognitive pharmaceutical services in Danish community pharmacies-perceptions of strategists and practitioners. Int. J. Pharm. Pract. 2006, 14, 37-49. [CrossRef]

7. Abrahamsen, B.; Burghle, A.H.; Rossing, C. Pharmaceutical care services available in Danish community pharmacies. Int. J. Clin. Pharm. 2020, 42, 315-320. [CrossRef]

8. Koster, E.S.; Blom, L.; Philbert, D.; Rump, W.; Bouvy, M.L. The Utrecht Pharmacy Practice network for Education and Research: A network of community and hospital pharmacies in The Netherlands. Int. J. Clin. Pharm. 2014, 36, 669-674. [CrossRef] [PubMed]

9. Marinac, J.S.; Kuo, G.M. Characterizing the American college of clinical pharmacy practice-based research network. Pharmacotherapy 2010, 30, 865. [CrossRef]

10. Mott, D.A.; Chater, R. Collaborations to facilitate success of community pharmacy practice-based research networks. J. Am. Pharm. Assoc. 2008, 48, 153-162.

11. Pruchnicki, M.C.; Rodis, J.L.; Beatty, S.J.; Clark, C.; McAuley, J.W.; Mehta, B.H.; Pedersen, C.A.; Protus, B.; Bennett, M.S. Practicebased research network as a research training model for community/ambulatory pharmacy residents. J. Am. Pharm. Assoc. 2008, 48, 191-202. [CrossRef]

12. Lindsey, L.; Husband, A.; Steed, L.; Walton, R.; Todd, A. Helpful advice and hidden expertize: Pharmacy users' experiences of community pharmacy accessibility. J. Public Health Engl. 2017, 39, 609-615. [CrossRef] [PubMed]

13. Apotekerforeningen. Lægemidler i Danmark 2019-20. Available online: https://www.apotekerforeningen.dk/-/media/ apotekerforeningen/stoerre_publikationer/laegemidler-i-danmark-2019-2020.pdf?la=da\&hash=105F8904B093616CBFFB534 2BAA1ABEBCB05C56E (accessed on 8 December 2020).

14. Burghle, A.; Abrahamsen, B.; Lundby, C.; Rossing, C.; Hansen, R.N.; Nørgaard, L.S.; Pottegård, A. Customers' information seeking behavior prior to community pharmacy visits: A community pharmacy survey. Res. Soc. Adm. Pharm. 2019, 16, 1442-1446. [CrossRef]

15. Hansen, N.R.; Nørgaard, L.; Hedegaard, U.; Søndergaard, L.; Servilieri, K.; Bendixen, S.; Rossing, C. Integration of and visions for community pharmacy in primary health care in Denmark. Pharm. Pract. 2021, 19, 1-9.

16. Danish Regions. Available online: https://www.regioner.dk/services/in-english (accessed on 9 June 2021).

17. KL—Local Government Denmark. Available online: https:/ / www.kl.dk/english/ (accessed on 9 June 2021).

18. Danish Medicines Agency. Over-the-Counter Medicines. Available online: https://laegemiddelstyrelsen.dk/en/pharmacies/ over-the-counter-medicines/ (accessed on 23 April 2021).

19. Apotekerforeningen. Sammen Forebygger vi Bedst. Available online: https://www.apotekerforeningen.dk/-/media/ apotekerforeningen/publikationer/apotekets-folder-sammen-forebygger-vi-bedst.pdf (accessed on 8 December 2020).

20. Herborg, H.; Sørensen, E.W.; Frøkjaer, B. Pharmaceutical care in community pharmacies: Practice and research in Denmark. Ann. Pharmacother. 2007, 41, 681-689. [CrossRef] [PubMed]

21. Benrimoj, S.I.; Feletto, E.; Wilson, L. Building Organisational Flexibility to Promote the Implementation of Primary Care Services in Community Pharmacy. 2015. Available online: https:/ /6cpa.com.au/wp-content/uploads/Building-OrganisationFlexibility-to-Promote-the-Implementation-of-Primary-Care-Service-in-Community-Pharmacy-Final-Report.pdf (accessed on 28 August 2020).

22. Danish Network for Community Pharmacy Practice Research and Development. Available online: https://www.pharmakon.dk/ forskning/apoteksnetvaerk/ (accessed on 15 February 2021).

23. Jørgensen, A.M.; Windsor, P.B.; Nørgaard, L.S.; Pottegaard, A.; Hansen, R.B. Patient Characteristics among Users of Proton Pumpinhibitors (PPI) in Danish Pharmacy Settings. 2019. Available online: https://linkinghub.elsevier.com/retrieve/pii/S15517 4111930854X (accessed on 10 June 2021).

24. Reduktion i Langtidsbehandling Med Protonpumpe-Hæmmere (PPI). Available online: https://www.youtube.com/watch?v= JXrmwd6kF-c (accessed on 17 February 2021).

25. Apotekskunders Informationssøgning før Apoteksbesøg. Available online: https://www.youtube.com/watch?v=Dp3nDcqlWzw (accessed on 17 February 2021).

26. Stampe, G. Tværfagligt Samarbejde Mellem Apotek og Almen Praktiserende Læge. Available online: https://www.pharmakon. $\mathrm{dk} /$ media/1911/2018_specialeafhandling_gitte-stampe_final.pdf (accessed on 28 January 2021).

27. Lundby, C.; Nielsen, A.V.; Bendixen, S.; Almarsdóttir, A.B.; Pottegård, A. Unavailable prescriptions at Danish community pharmacies: A descriptive study. Int. J. Clin. Pharm. 2019, 41, 672-676. [CrossRef]

28. Nielsen, A.V. Help Please-My Prescription is Unavailable! Occurrence and Underlying Reasons for Unavailable Prescriptions and the Development of a Protocol for Dependent Pharmacist Repeat Prescribing at Danish Community Pharmacies. Available online: https: / / www.pharmakon.dk/media/1896/masters-thesis-anne-vejrum-nielsen-mwt233.pdf (accessed on 28 January 2021).

29. Kutlu, Z. Danish Physicians' and Pharmacists' Knowledge, Attitude and Behavior on Antibiotics for Children under the Age of 15. Available online: https://www.pharmakon.dk/media/1907/speciale_zueleyha-kutlu.pdf (accessed on 28 January 2021).

30. Pultz, K.; Rikke, N.H.; Rossing, R.C. Afprøvning af Medicinmøder Med Hjemmeplejen. Available online: https://www. pharmakon.dk/media/1417/rapport-v2-afproevning-af-medicinmoeder_web.pdf (accessed on 28 January 2021). 
31. Valentin, J. Evaluering af det Danske Netværk Indenfor Udvikling af Apotekspraksis. Available online: https://www. pharmakon.dk/media/1864/isa-evaluering-af-det-danske-netvaerk-indenfor-udvikling-af-apotekspraksis.pdf (accessed on 28 January 2021).

32. Nørgaard, L.S.; Hansen, R.N.; Søndergaard, L.; Servilieri, K.M.; Bendixen, S.O. The Danish Network for Community Pharmacy Practice Research and Development. 2019. Available online: https://linkinghub.elsevier.com/retrieve/pii/S155174111930854X (accessed on 11 June 2021).

33. Ayoub, W. Kommunikation Mellem Apotekspersonale og Ældre af Anden Etnisk Baggrund End Dansk. Available online: https: / / www.pharmakon.dk/media/1946/kort-rapport-kommunikation-mellem-apotekspersonale-og-aeldre-af-anden-e_pdf (accessed on 28 January 2021).

34. Kristiansen, S.; Nørgaard, L.S.; Paltoft, S. COVID-19-Seen through the Eyes of the Pharmacy Interns. 2020. Available online: https:/ / pharmacyeducation.fip.org/pharmacyeducation/article/view/1157 (accessed on 11 June 2021).

35. Elberg, M.D. The Pharmacy's Experiences with Abuse of Over-the-Counter Medicines. Available online: https://www. pharmakon.dk/media/2210/martin-damm-elberg_162645_83913_hovedopgave_apotekets-erfaringer-med-misbrug-afhandkobslagemidler.pdf (accessed on 16 April 2021).

36. Kaae, S.; Nørgaard, L.S.; Sporrong, S.K.; Almarsdottir, A.B.; Kofoed, M.; Daysh, R.F.; Jowkar, N. Patients', Pharmacy Staff Members', and Pharmacy Researchers' Perceptions of Central Elements in Prescription Encounters at the Pharmacy Counter. Pharmacy 2019, 7, 84. [CrossRef] [PubMed]

37. Fosgerau, C.F.; Kaae, S. Furthering patient-centered counseling: Exploring new aspects around pharmacists' experiences in pharmacy encounters through video-stimulated recall interviewing. Res. Soc. Adm. Pharm. 2020, 17, 723-732. [CrossRef]

38. Lech, L.V.J.; Husted, G.R.; Almarsdottír, A.B.; Andersen, T.R.H.; Rossing, C.; Nørgaard, L.S. Hospital and Community Pharmacists' Views of and Perspectives on the Establishment of an Intraprofessional Collaboration in the Transition of Care for Newly Discharged Patients. Innov. Pharm. 2020, 11, 4. [CrossRef] [PubMed]

39. Lech, L.V.; Husted, G.R.; Rossing, C.; Andersen, T.R.H.; Almarsdóttir, A.B.; Nørgaard, L.S. Establishing an inter-professional collaboration between hospital and community pharmacy pharmacists in Denmark. 2019. Available online: https://linkinghub. elsevier.com/retrieve/pii/S155174111930854X (accessed on 11 June 2021). 